\title{
Lung penetration and patient adherence considerations in the management of asthma: role of extra-fine formulations [Corrigendum]
}

Scichilone N, Spatafora M, Battaglia S, Arrigo R, Benfante A, Bellia V. J Asthma Allergy. 2013;6:11-21.

On page 13, Figure 1 was incorrect. The corrected figure is:

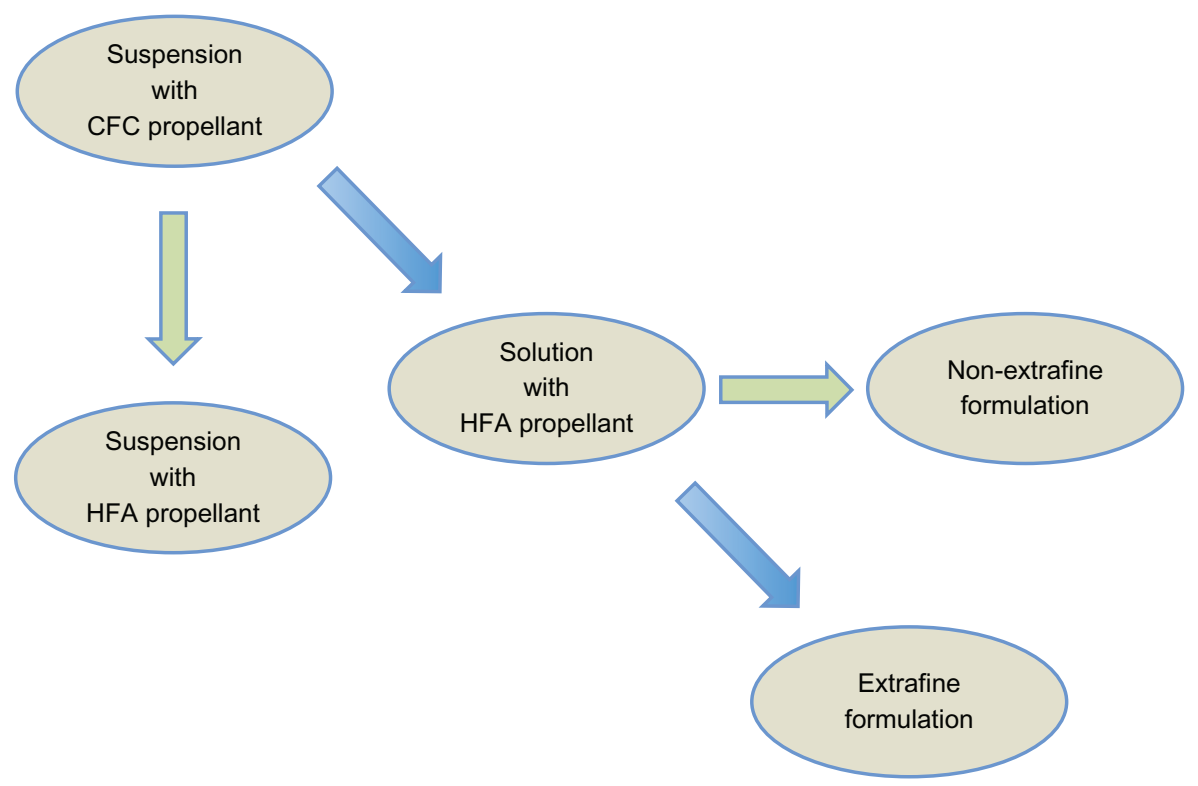

Figure I Algorithm showing the switch from chlorofluorocarbon (CFC) to hydrofluoroalkane (HFA) propellants and development of extra-fine formulations.

Journal of Asthma and Allergy

\section{Publish your work in this journal}

The Journal of Asthma and Allergy is an international, peer-reviewed open-access journal publishing original research, reports, editorials and commentaries on the following topics: Asthma; Pulmonary physiology; Asthma related clinical health; Clinical immunology and the immunological basis of disease; Pharmacological interventions and new therapies. Issues of patient safety and quality of care will also be considered. The manuscript management system is completely online and includes a very quick and fair peer-review system, which is all easy to use. Visit http://www.dovepress.com/testimonials.php to read real quotes from published authors. 